\title{
Pre-industrial glassmaking in the Swiss Jura: the refractory earth for the glassworks of Derrière Sairoche (ct. Bern, 1699-1714)
}

\author{
G. ERAMO \\ Department of Geosciences, Mineralogy and Petrography, \\ University of Fribourg, Chemin du Musée, 6, CH-1700, Fribourg, \\ Switzerland (e-mail: giacomo.eramo@unifr.ch)
}

\begin{abstract}
Fragments of the melting furnace and several crucibles of the glassworks of Derrière Sairoche are compared with local raw materials. Principal component analysis (PCA) based on the chemical composition and on the grain-size distribution of the archaeological and natural materials demonstrates that the analysed samples were made from the same raw material and that local clayey sands (Hupper, Sidérolithique) were exploited. Availability in situ of good raw materials made tempering unnecessary. Their high melting point $\left(\right.$ c. $\left.1600{ }^{\circ} \mathrm{C}\right)$ allowed good performance in service conditions at temperatures up to $1500{ }^{\circ} \mathrm{C}$. Moreover, because of low $\mathrm{Fe}_{2} \mathrm{O}_{3 \text { tot }}$ concentrations, batch-glass contamination was avoided.
\end{abstract}

In the Middle Ages the spread of wood-ash glass production ('Waldglas') in northern Europe implied substantial changes from the natron glass produced in antiquity. The high $\mathrm{CaO}$ (10-20 wt $\%)$ content of the former required higher melting temperatures (up to $1400{ }^{\circ} \mathrm{C}$ ) than the $1000-1100{ }^{\circ} \mathrm{C}$ range sufficient for the ancient $\mathrm{Na}-\mathrm{Ca}$ glasses (Turner 1956; Cable \& Smedley 1987; Cable 1998; Brill 1999; Henderson 2000; Stern \& Gerber 2004). To reach temperatures up to $1400{ }^{\circ} \mathrm{C}$, a more efficient pyrotechnology and better performing refractory materials were necessary (Charleston 1978; Cable 1998; Eramo 2005a).

Recent studies on the pre-industrial glassworks of Derrière Sairoche (1699-1714) discussed some aspects of glass technology in the Bernese Jura (Gerber 2003; Stern \& Gerber 2004; Eramo 2005a). In this area, dozens of glassworks were active during the second half of the 17th and the first half of the 18th century (Sveva Gai 1991; Sternini 1995). Here, glassmakers found pure quartz sand (see below) as well as extensive forests and streams to transport wood (Amweg 1941; Michel 1989; Gerber et al. 2002). Stern (1991) reported a Ca-K composition for glasses from this area and made glass replicas using local quartz sand and wood ash (Stern \& Gerber 2004). Several outcrops of pure quartz sand and refractory earth are historically known near Derrière Sairoche (Schlaich 1934; Amweg 1941); however, to obtain a better understanding of the role of the raw materials and their influence on local glass technology, an archaeometric characterization appears necessary. In a recent paper Eramo $(2005 b)$ showed that the crucible samples of Derrière Sairoche were not tempered with recycled crucibles and refractory fragments ('grog') as suggested in old glassmaking treatises. Nevertheless, some processing of the raw materials cannot be excluded (e.g. sand tempering). This paper attempts to prove, by multivariate analysis of the grain-size and chemical data, whether or not the unprocessed local raw materials (Hupper, Sidérolithique) could be technologically suitable to produce the crucibles and the refractory samples, and whether or not there are compositional differences between crucibles and refractory samples for technological reasons.

\section{The Sidérolithique}

The name Sidérolithique was introduced in the geological literature by Thurmann (1836) and is still used to indicate a complex geological unit deposited during the Eocene (Early Oligocene?) on the karstified surface of the Mesozoic limestones in the Jura region. The accumulation of different lithologies (i.e. kaolinitic clays, iron pisoliths, quartz sand, etc.) occurring in karstic pockets, or rarely as continuous beds (e.g. valley of Delémont) (Fleury 1909; Schlaich 1934; von Moos 1941; Aubert 1975; Pfirter 1997), marks the stratigraphic limit between Mesozoic limestones and Molasse sediments 

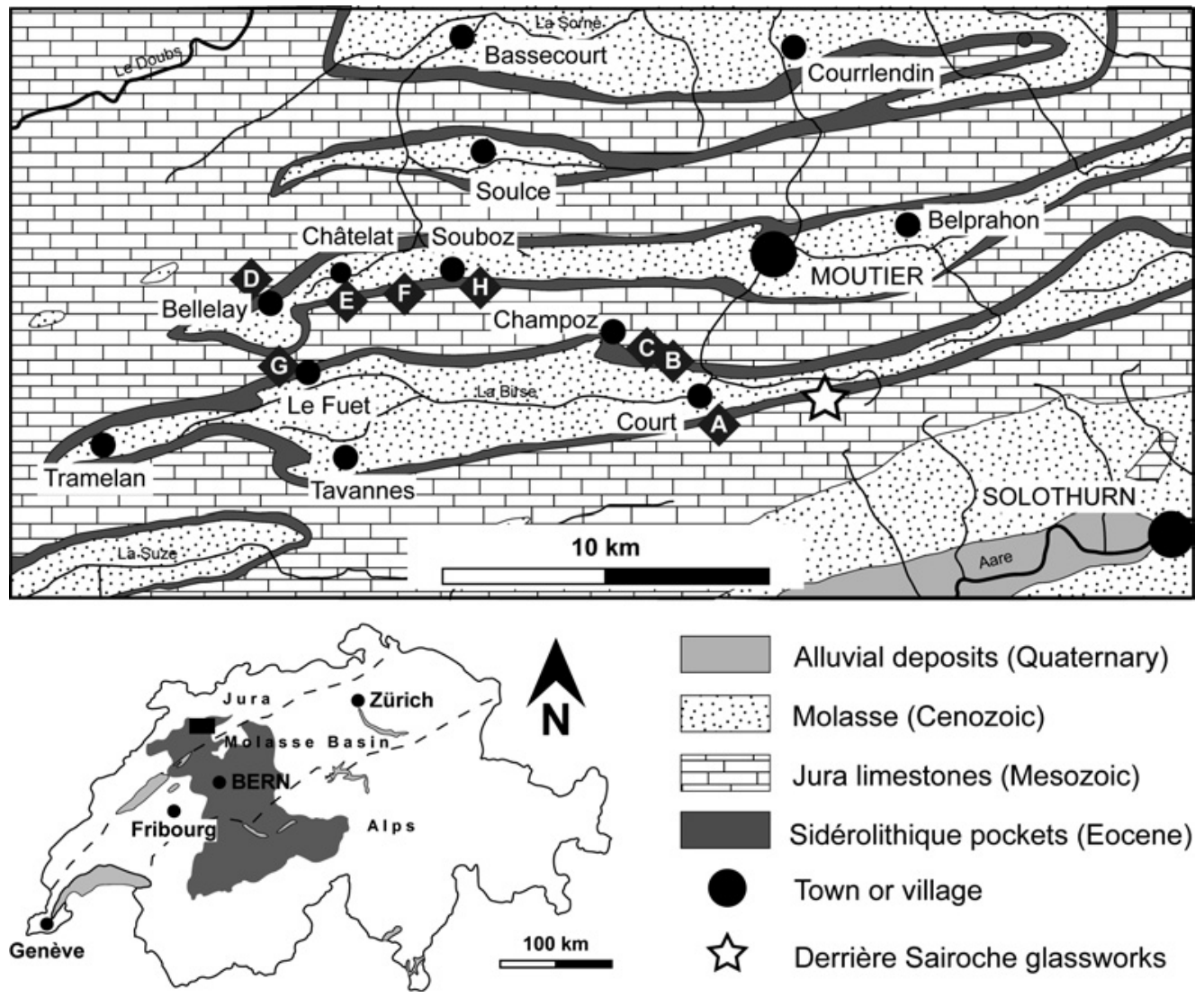

Fig. 1. Schematic geological map of the Court area (shown by the black rectangle in the outline map of Switzerland), in the northern part of canton Bern (shaded area in the outline map). Location of the Hupper sand samples: A, Sur Frête; B, Lac Vert; C, Champoz-P. Mont Girod; D, Forêt de Bérole; E, Châtelat; F, Monible-Côte; G, La Fuet;

$\mathrm{H}$, Souboz-Montaigu.

throughout the Jura region (Fig. 1). Generally, the outcrops are distributed along the flanks of the valleys of the Jura belt. As these terrains do not have lateral continuity, they may occur in several associations or some lithologies may be lacking. The Sidérolithique is composed of red or yellow clays (rarely white, green or violet) called Bolus; levels rich in iron pisoliths (Bohnerz); quartz sands that can sometimes be clayey (Hupper) and calcareous conglomerate (Gompholithe) containing iron pisoliths.

The chemical composition of Hupper varies as a function of clay content. $\mathrm{Al}_{2} \mathrm{O}_{3}$ concentrations up to $15 \mathrm{wt} \%$ for clay-rich samples were reported by De Quervain (1969). Hoffmann \& Peters (1969) reported kaolinite as the major clay mineral (70-90 wt\%) and illite and montmorillonite as minor components $(0-10 \mathrm{wt} \%)$ in the grain-size fraction $<2 \mu \mathrm{m}$. Hupper layers rich in clay were quoted as suitable for refractory materials by Fleury (1909). Their melting point exceeds $1500{ }^{\circ} \mathrm{C}$ (von Moos 1941; Hoffmann \& Peters 1969). On the other hand, the quartz sand (up to 99 wt $\% \mathrm{SiO}_{2}$ ) was exploited since the Middle Ages as a raw material for glass (Fleury 1909; Amweg 1941; Kündig et al. 1997).

\section{Sampling strategy}

The glassworks of Derrière Sairoche is located in the valley of Chaluet (Bernese Jura) with several outcrops of Hupper nearby (Fig. 1). The exploitation of some of these outcrops for glass, refractory and ceramic production has been described in the literature (Fleury 1909; Schlaich 1934; von Moos 1941; De Quervain 1969). To prove the utilization of natural raw materials suitable to produce the crucibles and the refractory 
Table 1. Analysed samples of Hupper sand (Sidérolithique)

\begin{tabular}{|c|c|c|c|}
\hline Sample & Coordinates & Locality & Mineral content \\
\hline ER125 & $591.510 / 231.200$ & Sur Frête & Qtz + Kln \\
\hline ER126 & $591.510 / 231.200$ & Sur Frête & $\mathrm{Qtz}+\mathrm{Kln}+\mathrm{Goe}$ \\
\hline ER127 & $591.510 / 231.200$ & Sur Frête & $\mathrm{Qtz}+\mathrm{K} \ln$ \\
\hline ER131 & $591.075 / 233.150$ & Lac Vert & $\mathrm{Qtz}+\mathrm{Kln}$ \\
\hline ER136 & $591.075 / 233.150$ & Lac Vert & $\mathrm{Qtz}+\mathrm{Kln}+(\mathrm{Cal})$ \\
\hline ER137 & $591.075 / 233.150$ & Lac Vert & $\mathrm{Qtz}+\mathrm{Kln}$ \\
\hline ER138 & $591.075 / 233.150$ & Lac Vert & $\mathrm{Qtz}+\mathrm{Kln}$ \\
\hline ER139 & $591.075 / 233.150$ & Lac Vert & $\mathrm{Qtz}+\mathrm{Kln}+\mathrm{Ill} / \mathrm{Mus}$ \\
\hline ER140 & $590.300 / 233.625$ & Champoz-P. Mont Girod & $\mathrm{Qtz}+\mathrm{Kln}$ \\
\hline ER141 & $590.300 / 233.625$ & Champoz-P. Mont Girod & Qtz + Kln \\
\hline ER248 & $579.620 / 235.230$ & Forêt de Bérole & $\begin{array}{c}\mathrm{Qtz}+\mathrm{Kln}+\mathrm{Ill} / \mathrm{Mus} \\
+\mathrm{Chl}+\mathrm{Kf}+\mathrm{Pl}\end{array}$ \\
\hline ER249 & $581.370 / 235.510$ & Châtelat & $\mathrm{Qtz}+\mathrm{K} \ln$ \\
\hline ER250 & $581.370 / 235.510$ & Châtelat & $\mathrm{Qtz}+\mathrm{Kln}$ \\
\hline ER251 & $582.140 / 235.490$ & Monible-Côte & $\mathrm{Qtz}+\mathrm{Kln}$ \\
\hline ER252 & $582.140 / 235.490$ & Monible-Côte & $\mathrm{Qtz}+\mathrm{Kln}$ \\
\hline ER253 & $580.100 / 232.700$ & La Fuet & $\mathrm{Qtz}+\mathrm{Kln}+\mathrm{Cal}$ \\
\hline ER254 & $580.100 / 232.700$ & La Fuet & $\mathrm{Qtz}+\mathrm{K} \ln$ \\
\hline ER255 & $586.750 / 235.875$ & Souboz-Montaigu & Qtz + Kln \\
\hline ER256 & $586.700 / 236.000$ & Souboz-Montaigu & $\mathrm{Qtz}+\mathrm{Kln}+(\mathrm{Cal})$ \\
\hline
\end{tabular}

Mineral abbreviations as in Kretz (1983): Qtz, quartz; Kln, kaolinite; Cal, calcite; Goe, goethite; Chl, chlorite; Ill, illite; Mus, muscovite; Kf, potassium feldspar; Pl, plagioclase.

material, only those outcrops having somewhat plastic materials were chosen for sampling (Fig. 1). In some cases it was possible to sample sediments of different grain-size distributions (Lac Vert, Souboz-Montaigu and Sur Frête). Nineteen samples of Hupper were collected (Table 1).

The analytical methods used in this study and a discussion of the precision of the grain-size analyses are given in the Appendix.

\section{Results}

\section{Hupper sand}

Petrography and mineralogy. The clastic portion of the samples consists of mono- and, rarely, polycrystalline quartz. The grains are angular to subrounded (Fig. 2a). The argillaceous matrix consists of kaolinite (determined by X-ray diffraction; XRD) and is sometimes brown because of the presence of iron hydroxides and
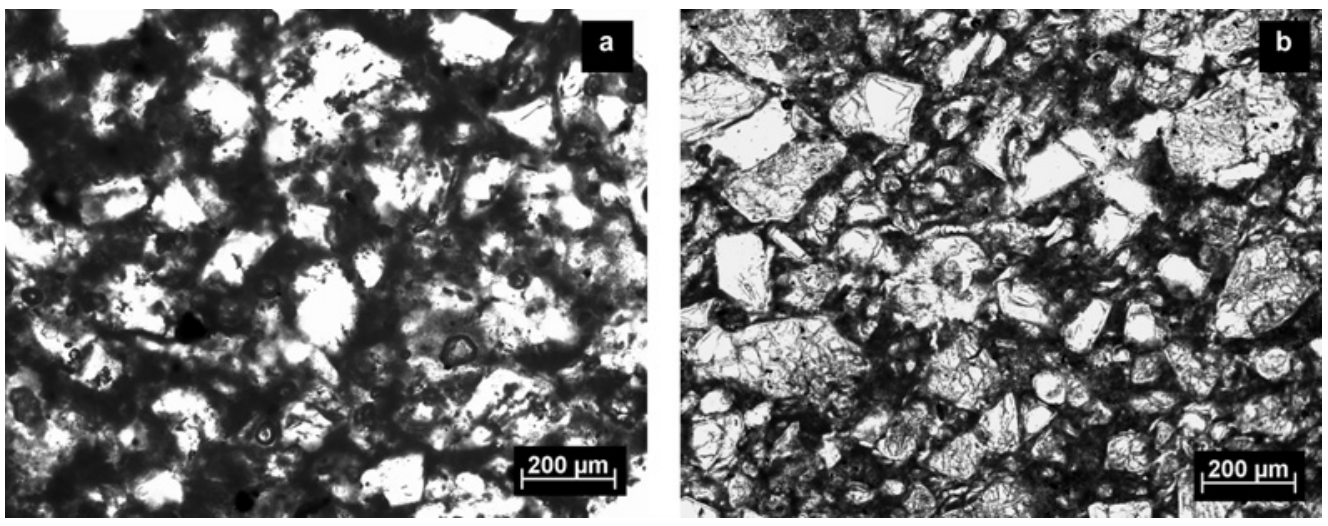

Fig. 2. Optical microphotographs (5×, plane-polarized light) of a Hupper sand sample (a, ER250) and of a crucible fragment (b, ER52). 
oxides. Some calcite is present in ER136, 253 and 256, and ferruginous aggregates were detected in ER126 and 248. This latter sample contains small amounts of K-feldspar, plagioclase, muscovite-illite and chlorite (Table 1).

Chemistry. Bulk chemical compositions of the samples are characterized by high percentages of $\mathrm{SiO}_{2}$. Except for $\mathrm{Al}_{2} \mathrm{O}_{3}$, the other oxides are generally $<1 \mathrm{wt} \%$. On the whole, the concentrations of the trace elements are low $(<100 \mathrm{ppm})$, except for $\mathrm{Zr}$ (Table 2).

Grain-size analysis (sieving). Table 3 shows grain-size data for Hupper sand. The cumulative frequency curves (Fig. 3) show the grain-size variability in the sampling area. Almost all samples are poor in coarse sand $(<-1 \phi$ and $-1-0 \phi)$ and show a large dispersion of fine sand $(3-4 \phi)$ and 'silt + clay' $(>4 \phi)$ percentages. ER139 and 248 consist of $>95 \mathrm{wt} \%$ of silt and clay. The samples from Lac Vert and Souboz-Montaigu show the widest grain-size variability in the same outcrop.

\section{Crucibles and refractory fragments}

As reported by Eramo $(2005 a, b)$ both the refractory and the crucible fragments are composed almost completely of $\mathrm{SiO}_{2}$ and $\mathrm{Al}_{2} \mathrm{O}_{3}$. Contents of $\mathrm{Fe}_{2} \mathrm{O}_{3 \text { tot }}$ and $\mathrm{TiO}_{2}$ are generally $<1 \mathrm{wt} \%$ (Table 2). Monocrystalline and, rarely, polycrystalline quartz grains were detected as non-plastic inclusions originally present in the raw material (Fig. 2b). Quartz grains, partially thermally transformed to tridymite and cristobalite, are surrounded by a low-birefringent matrix composed of cristobalite and mullite. Although the XRD spectra show very low background, the presence of a glassy phase cannot be excluded.

Grain-size analysis (thin section). The results of the grain-size analysis in thin section of the crucible and furnace fragments are shown in Table 4. Both types of samples are characterized by low percentages of coarse sand and by an increase of standard deviation values for finer size classes. The cumulative frequency curves of crucible fragments are similar to one another (Fig. 4a) and show $2-3 \phi$ and $3-4 \phi$ values more dispersed than those of the refractory samples (Fig. 4b). The crucible samples ER23, 48 and 52 are richer in silt and clay than the others.

\section{Data processing}

In general, the petrographical and chemical features of the analysed Hupper sand samples are consistent with those of the refractory and crucible samples reported by Eramo $(2005 a, b)$. In both natural and archaeological materials, monocrystalline quartz forms the non-plastic portion, whereas $\mathrm{Al}_{2} \mathrm{O}_{3}$ percentages are related to mullite or original kaolinite. Furthermore, the grain-size analyses carried out on the archaeological and natural materials show that most of the samples have similar grain-size distribution curves (Figs 3 and 4). A multivariate statistical analysis using both chemical and grain-size variables appeared useful to compare the Hupper sand with the crucibles and refractory samples. Principal component analysis (PCA) was carried out on the complete dataset (84 samples: 43 crucibles, 22 refractories, 19 Hupper sand) using chemical and grain-size variables, which have few missing values and higher variance (Table 5). The ' $<0.01$ ' in the dataset were approximated to 0.01 . As the 14 variables $\left(\mathrm{SiO}_{2}, \mathrm{TiO}_{2}, \mathrm{Al}_{2} \mathrm{O}_{3}, \mathrm{Fe}_{2} \mathrm{O}_{3 \text { tot }}, \mathrm{MgO}\right.$, $\mathrm{CaO}, \mathrm{K}_{2} \mathrm{O}, \mathrm{Cr}, \mathrm{Sr}, \mathrm{Zr}, 1-2 \phi, 2-3 \phi, 3-4 \phi$ and $>4 \phi$ ) used for the PCA are expressed in different units, standardization was necessary to ensure a similar order of magnitude and variance. The contributions to the total variance and the loadings of the first three principal components (PCs) are shown in Table 6. PC1 is very dominant and accounts for $41.78 \%$ of total variance. This component is characterized by negative loadings of $\mathrm{SiO}_{2}$ and sand fractions and by the association of $\mathrm{Al}_{2} \mathrm{O}_{3}, \mathrm{~K}_{2} \mathrm{O}, \mathrm{Cr}$ and pan fraction. Although some associations occurring in $\mathrm{PC} 1$ are still present, PC2 features higher variances of $1-2 \phi$ and $3-4 \phi$. The $2-3 \phi$ contribution to the total variance of PC2 and PC3 is very low compared with $\mathrm{PC} 1$, giving different information about the data structure. Whereas PC2 is characterized by high loadings of $1-2 \phi$ and $3-4 \phi, \mathrm{PC} 3$ features high loadings of $\mathrm{Zr}, \mathrm{MgO}$, $\mathrm{Al}_{2} \mathrm{O}_{3}$ and Sr. The component plot PC1 v. PC2 (Fig. 5a) shows strong positive correlations between $\mathrm{K}_{2} \mathrm{O}$ and the pan fraction, $\mathrm{TiO}_{2}$ and $\mathrm{Zr}, \mathrm{Fe}_{2} \mathrm{O}_{3 \text { tot }}$ and $\mathrm{MgO}$, and between $\mathrm{SiO}_{2}$ and $2-3 \phi$. This last association of variables is negatively correlated with $\mathrm{K}_{2} \mathrm{O}$ and pan fraction and, to a lesser extent, with the other variables located in the positive quadrants of the diagram. The PC1 v. PC3 diagram shows less obvious correlation, such as $\mathrm{Zr}-\mathrm{MgO}$ or $\mathrm{Sr}-\mathrm{Al}_{2} \mathrm{O}_{3}$ and $\mathrm{Cr}->4 \phi$ (Fig. 5b). These relations between variables may be interpreted as the chemical and grain-size signature of the studied materials. PC2 provides a more grain-size-sensitive 


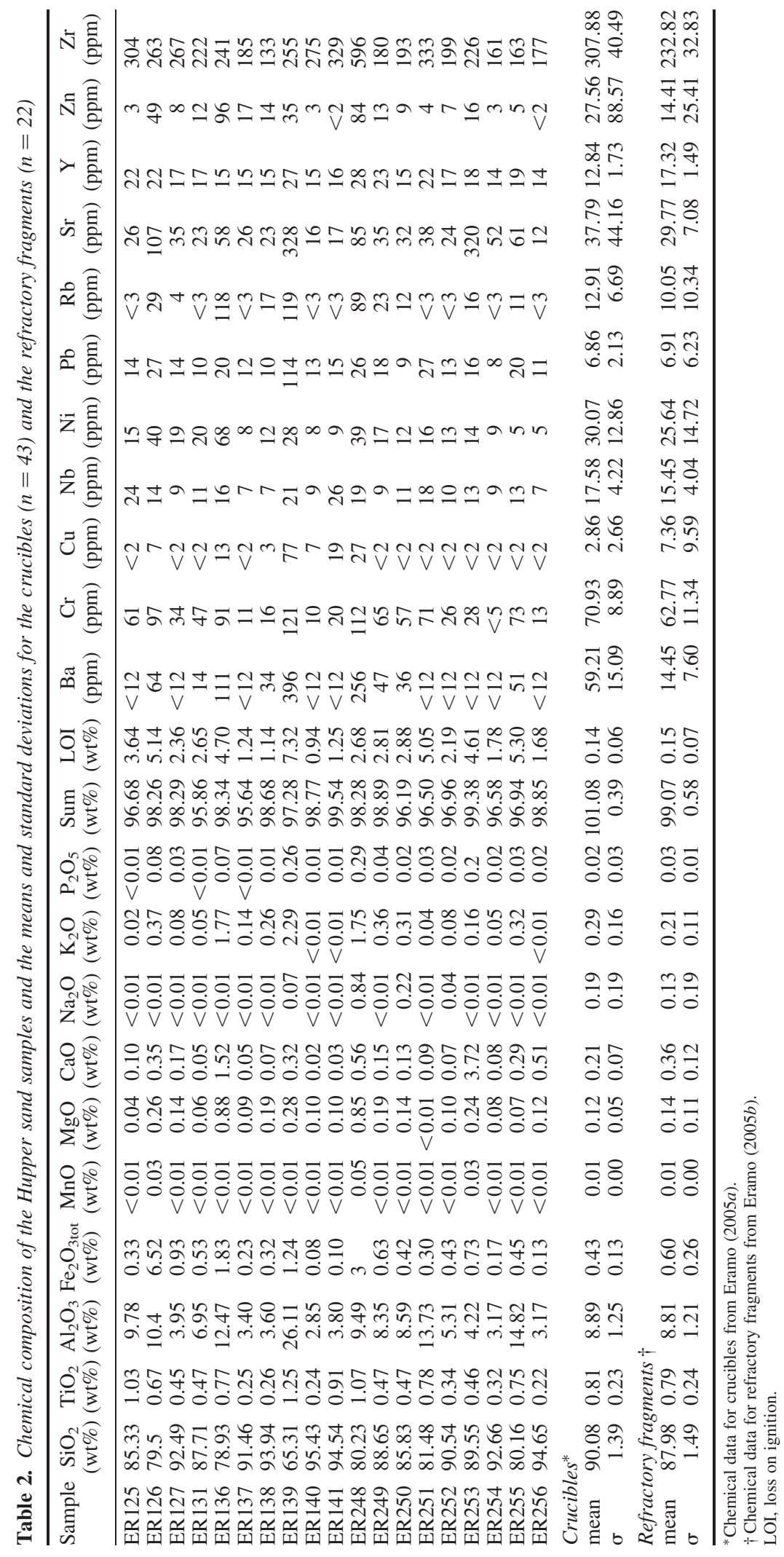


Table 3. Grain-size data for the Hupper sand samples by sieving (wt\%)

\begin{tabular}{llllrrrr}
\hline$\phi:$ & $<-1$ & $-1-0$ & $0-1$ & $1-2$ & $2-3$ & $3-4$ & $>4$ \\
mm: & $>2$ & $1-2$ & $0.5-1$ & $0.25-0.5$ & $0.125-0.25$ & $0.063-0.125$ & $<0.063$ \\
\hline ER125 & 0.00 & 0.23 & 1.65 & 9.35 & 22.19 & 21.33 & 45.24 \\
ER126 & 7.47 & 0.46 & 1.45 & 9.30 & 19.09 & 9.40 & 52.82 \\
ER127 & 0.54 & 0.05 & 2.80 & 16.79 & 28.97 & 21.70 & 29.16 \\
ER131 & 0.14 & 0.32 & 1.38 & 6.48 & 24.76 & 1.22 & 65.71 \\
ER136 & 0.78 & 0.02 & 0.23 & 8.07 & 14.72 & 9.01 & 67.18 \\
ER137 & 0.02 & 0.27 & 3.97 & 26.09 & 38.81 & 15.77 & 15.07 \\
ER138 & 0.00 & 0.18 & 2.34 & 25.61 & 39.18 & 15.59 & 17.10 \\
ER139 & 0.00 & 0.04 & 0.22 & 0.85 & 1.50 & 2.56 & 94.84 \\
ER140 & 0.02 & 0.22 & 3.24 & 35.81 & 21.84 & 16.50 & 22.37 \\
ER141 & 0.00 & 0.02 & 1.22 & 23.39 & 34.85 & 23.37 & 17.16 \\
ER248 & 0.04 & 0.04 & 0.06 & 0.30 & 0.98 & 1.96 & 96.62 \\
ER249 & 0.34 & 0.80 & 4.28 & 16.76 & 25.76 & 14.40 & 37.66 \\
ER250 & 0.30 & 0.86 & 3.46 & 15.54 & 28.96 & 14.58 & 36.30 \\
ER251 & 0.90 & 0.78 & 1.06 & 7.46 & 33.14 & 19.58 & 37.08 \\
ER252 & 0.08 & 0.82 & 4.20 & 16.38 & 28.74 & 19.38 & 30.40 \\
ER253 & 3.76 & 0.32 & 1.96 & 7.30 & 16.86 & 22.72 & 47.08 \\
ER254 & 0.00 & 0.02 & 1.00 & 5.48 & 15.32 & 16.20 & 61.98 \\
ER255 & 0.30 & 0.32 & 0.82 & 2.62 & 21.06 & 8.14 & 66.74 \\
ER256 & 1.68 & 0.84 & 4.60 & 20.70 & 35.10 & 17.88 & 19.20 \\
\hline
\end{tabular}

fingerprint of the dataset, whereas $\mathrm{PC} 3$ is rather chemistry-sensitive. The $\mathrm{Al}_{2} \mathrm{O}_{3}, \mathrm{~K}_{2} \mathrm{O}$ and pan fraction positive correlation reflects the presence of these two oxides in clay minerals, whereas those of $\mathrm{CaO}, \mathrm{MgO}$ and $\mathrm{Sr}$ may be explained as a co-occurrence in minor amounts of calcareous clasts that are present. Although PC1, PC2 and PC3 account only for $66.07 \%$ of the total variance, their bivariate plots show a close distribution and a complete overlap of the refractory and crucibles data points (Fig. $5 \mathrm{c}$ and d). In contrast, Hupper sand data points are more dispersed and only ER125 and 251 fall in the region of crucible and refractory fragments if PC1 and PC2 are considered (Fig. 5c), whereas in the PC1 v. PC3 plot, ER131, 249, 250 and 254 also fit the archaeological materials (Fig. 5d). According to the position of the data points, it can be inferred that the archaeological materials are characterized by a high content of fine quartz sand and a low content of clay, Fe-oxides and calcareous fragments. Summarizing, a large number of natural samples fit the archaeological materials from a chemical point of view, whereas the grain-size distribution is a more stringent factor to fit the archaeological materials.

\section{Discussion and conclusions}

Grain-size analysis by sieving and by point counting on natural and archaeological samples, respectively, added the grain-size distribution variable as a tool not commonly used in provenance studies of ceramic materials.
Multivariate statistics involving chemical and grain-size variables revealed that the refractory and crucible samples analysed were made with the same raw materials.

Chemical, petrographical and grain-size characteristics of the Hupper sand samples collected in the proximity of Derrière Sairoche show their compatibility with the crucibles and refractory fragments. As stated in the introduction there is historical evidence for exploitation of refractory earth and pure quartz sand in the Berner Jura.

Although it was not possible to locate exactly the old pits, owing to their lack of accessibility, it could be shown that the analysed samples cover a wide grain-size and chemical range. Only ER125 and ER251 are really consistent with the archaeological materials if the most significant PCs are taken into account. Sur Frête (ER125) is the Hupper deposit closest to the glassworks, whereas Monible-Côte lies about $15 \mathrm{~km}$ away. Hence it is reasonable to consider Sur Frête as the most probable source of clayey sand. However, the occurrence of other suitable raw materials at a greater distance indicates that these features may be found in several places in the area. It must be kept in mind that the heterogeneity of Hupper sand and its stratigraphical position made possible the occurrence of good raw material almost everywhere in the Swiss Jura. Furthermore, availability in situ of good clayey sand made any further treatment unnecessary. The absence of recycled refractory and crucible fragments in refractory and crucible 

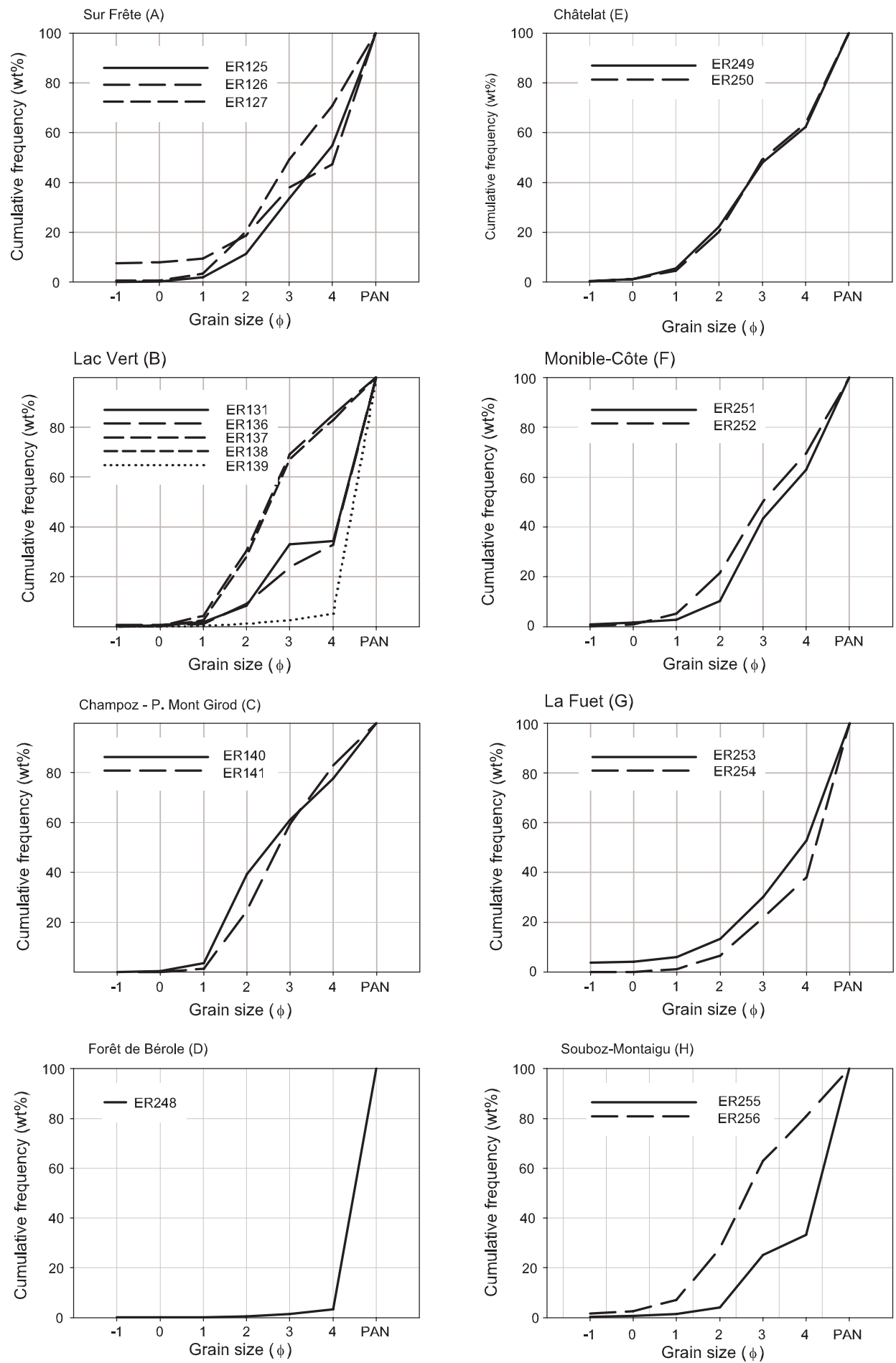

Fig. 3. Cumulative grain-size frequency curves of the Hupper sand samples (sieve analysis). 
Table 4. Grain-size data for the refractory and crucible samples by thin-section analysis (vol\%)

\begin{tabular}{|c|c|c|c|c|c|c|c|}
\hline $\begin{array}{l}\phi: \\
\mathrm{mm}:\end{array}$ & $\begin{array}{l}<-1 \\
>2\end{array}$ & $\begin{array}{c}-1-0 \\
1-2\end{array}$ & $\begin{array}{l}0-1 \\
0.5-1\end{array}$ & $\begin{array}{l}1-2 \\
0.25-0.5\end{array}$ & $\begin{array}{l}2-3 \\
0.125-0.25\end{array}$ & $\begin{array}{l}3-4 \\
0.063-0.125\end{array}$ & $\begin{array}{l}>4 \\
<0.063\end{array}$ \\
\hline \multicolumn{8}{|c|}{ Crucible fragments } \\
\hline ER21 & 0.00 & 0.00 & 3.92 & 8.81 & 16.15 & 26.10 & 45.02 \\
\hline ER22 & 0.00 & 0.09 & 1.04 & 12.16 & 22.51 & 26.50 & 37.70 \\
\hline ER23 & 0.00 & 0.00 & 1.71 & 7.62 & 9.14 & 12.95 & 68.57 \\
\hline ER24 & 0.00 & 0.77 & 1.93 & 10.89 & 27.12 & 19.32 & 39.98 \\
\hline ER25 & 0.00 & 0.00 & 2.25 & 13.30 & 24.75 & 14.85 & 44.85 \\
\hline ER26 & 0.00 & 0.19 & 4.08 & 6.21 & 21.17 & 31.26 & 37.09 \\
\hline ER27 & 0.00 & 0.00 & 2.96 & 11.50 & 23.98 & 17.48 & 44.08 \\
\hline ER28 & 0.00 & 0.00 & 4.64 & 12.96 & 28.43 & 23.98 & 29.98 \\
\hline ER29 & 0.00 & 0.00 & 3.50 & 8.47 & 26.34 & 29.10 & 32.60 \\
\hline ER30 & 0.00 & 0.00 & 1.38 & 10.80 & 33.45 & 23.43 & 30.93 \\
\hline ER31 & 0.00 & 0.00 & 2.64 & 7.91 & 21.66 & 23.16 & 44.63 \\
\hline ER32 & 0.00 & 0.00 & 1.88 & 4.33 & 29.94 & 23.35 & 40.49 \\
\hline ER33 & 0.00 & 0.00 & 1.09 & 3.83 & 25.32 & 23.68 & 46.08 \\
\hline ER34 & 0.00 & 0.00 & 0.39 & 7.56 & 26.16 & 26.16 & 39.73 \\
\hline ER35 & 0.00 & 0.00 & 0.39 & 5.10 & 23.92 & 41.18 & 29.41 \\
\hline ER36 & 0.00 & 0.20 & 2.15 & 10.67 & 27.25 & 19.86 & 39.87 \\
\hline ER37 & 0.00 & 0.00 & 0.86 & 6.39 & 21.59 & 42.31 & 28.84 \\
\hline ER38 & 0.00 & 0.00 & 2.75 & 9.17 & 21.83 & 29.54 & 36.70 \\
\hline ER39 & 0.00 & 0.25 & 3.96 & 9.66 & 28.15 & 18.14 & 39.84 \\
\hline ER40 & 0.00 & 0.00 & 1.99 & 7.40 & 22.56 & 34.84 & 33.21 \\
\hline ER41 & 0.00 & 0.00 & 1.43 & 6.51 & 21.75 & 31.11 & 39.21 \\
\hline ER42 & 0.00 & 0.00 & 0.98 & 5.69 & 26.67 & 32.55 & 34.12 \\
\hline ER43 & 0.00 & 0.27 & 1.43 & 9.17 & 33.05 & 22.79 & 33.29 \\
\hline ER44 & 0.00 & 0.00 & 0.98 & 3.54 & 25.20 & 36.61 & 33.66 \\
\hline ER45 & 0.00 & 0.00 & 1.28 & 4.95 & 27.11 & 33.88 & 32.78 \\
\hline ER46 & 0.00 & 0.00 & 3.57 & 5.35 & 23.53 & 27.81 & 39.75 \\
\hline ER47 & 0.00 & 0.00 & 0.51 & 8.81 & 22.37 & 32.88 & 35.42 \\
\hline ER48 & 0.00 & 0.00 & 2.51 & 5.20 & 16.67 & 20.79 & 54.84 \\
\hline ER49 & 0.00 & 0.00 & 1.62 & 7.94 & 21.48 & 25.27 & 43.68 \\
\hline ER50 & 0.00 & 0.00 & 2.66 & 6.45 & 22.77 & 32.26 & 35.86 \\
\hline ER51 & 0.00 & 0.00 & 2.91 & 4.73 & 20.18 & 24.00 & 48.18 \\
\hline ER52 & 0.00 & 0.72 & 0.72 & 4.15 & 14.26 & 19.49 & 60.65 \\
\hline ER53 & 0.00 & 1.71 & 0.57 & 7.60 & 25.67 & 33.08 & 31.37 \\
\hline ER54 & 0.00 & 0.00 & 0.91 & 6.92 & 26.05 & 32.24 & 33.88 \\
\hline ER55 & 0.00 & 0.00 & 1.48 & 3.87 & 29.52 & 33.76 & 31.37 \\
\hline ER56 & 0.00 & 0.00 & 1.69 & 4.14 & 21.09 & 25.05 & 48.02 \\
\hline ER57 & 0.00 & 0.00 & 1.47 & 7.56 & 29.46 & 24.79 & 36.72 \\
\hline ER58 & 0.00 & 0.00 & 1.98 & 5.49 & 28.51 & 39.02 & 25.00 \\
\hline ER59 & 0.00 & 0.00 & 1.13 & 7.16 & 26.74 & 32.39 & 32.58 \\
\hline ER60 & 0.00 & 0.10 & 0.93 & 8.55 & 31.12 & 25.11 & 34.20 \\
\hline ER61 & 0.00 & 0.00 & 0.56 & 6.40 & 19.59 & 39.36 & 34.09 \\
\hline ER62 & 0.00 & 0.00 & 1.19 & 5.25 & 21.02 & 37.63 & 34.92 \\
\hline ER65 & 0.00 & 0.00 & 0.97 & 4.65 & 25.78 & 38.57 & 30.04 \\
\hline mean & 0.00 & 0.10 & 1.84 & 7.32 & 24.21 & 28.08 & 38.45 \\
\hline$\sigma$ & 0.00 & 0.30 & 1.11 & 2.58 & 4.80 & 7.29 & 8.53 \\
\hline \multicolumn{8}{|c|}{ Refractory fragments } \\
\hline ER63 & 0.00 & 0.00 & 2.23 & 4.28 & 19.74 & 31.47 & 42.27 \\
\hline ER64 & 0.00 & 0.00 & 2.11 & 6.01 & 22.24 & 30.68 & 38.96 \\
\hline ER66 & 0.00 & 0.00 & 1.47 & 7.89 & 30.09 & 28.81 & 31.74 \\
\hline ER67 & 0.00 & 0.00 & 2.64 & 6.78 & 28.44 & 37.66 & 24.48 \\
\hline ER68 & 0.00 & 0.00 & 4.85 & 5.04 & 30.22 & 32.09 & 27.80 \\
\hline ER69 & 0.00 & 0.00 & 1.60 & 8.53 & 21.31 & 22.91 & 45.65 \\
\hline ER85 & 0.00 & 0.00 & 1.20 & 5.60 & 22.40 & 21.80 & 49.00 \\
\hline ER86 & 0.00 & 0.00 & 1.52 & 7.77 & 21.79 & 24.83 & 44.09 \\
\hline ER87 & 0.00 & 0.00 & 1.51 & 8.47 & 22.22 & 24.11 & 43.69 \\
\hline ER88 & 0.00 & 0.00 & 0.53 & 5.49 & 23.72 & 30.27 & 40.00 \\
\hline
\end{tabular}


Table 4. Continued

\begin{tabular}{lccccccc}
\hline$\phi:$ & $<-1$ & $-1-0$ & $0-1$ & $1-2$ & $2-3$ & $3-4$ & $>4$ \\
mm: & $>2$ & $1-2$ & $0.5-1$ & $0.25-0.5$ & $0.125-0.25$ & $0.063-0.125$ & $<0.063$ \\
\hline ER89 & 0.00 & 0.00 & 1.49 & 5.65 & 21.99 & 25.71 & 45.17 \\
ER90 & 0.00 & 0.00 & 0.00 & 3.14 & 25.65 & 41.14 & 30.07 \\
ER91 & 0.00 & 0.00 & 0.00 & 1.17 & 20.43 & 38.72 & 39.69 \\
ER102 & 0.00 & 0.00 & 0.59 & 2.55 & 27.50 & 43.42 & 25.93 \\
ER103 & 0.00 & 0.00 & 1.91 & 5.53 & 27.48 & 42.37 & 22.71 \\
ER267 & 0.00 & 0.00 & 0.95 & 7.44 & 33.21 & 34.92 & 23.47 \\
ER276 & 0.00 & 0.00 & 0.36 & 4.55 & 20.91 & 31.64 & 42.55 \\
ER277 & 0.00 & 0.00 & 0.54 & 4.83 & 20.75 & 31.13 & 42.75 \\
ER278 & 0.00 & 0.00 & 0.70 & 5.04 & 22.26 & 36.35 & 35.65 \\
ER279 & 0.00 & 0.00 & 3.02 & 4.34 & 25.66 & 40.00 & 26.98 \\
ER280 & 0.00 & 0.00 & 0.55 & 4.62 & 26.06 & 41.77 & 26.99 \\
ER281 & 0.00 & 0.00 & 3.91 & 4.84 & 26.82 & 35.75 & 28.68 \\
mean & 0.00 & 0.00 & 1.53 & 5.43 & 24.59 & 33.07 & 35.38 \\
$\sigma$ & 0.00 & 0.00 & 1.24 & 1.87 & 3.74 & 6.66 & 8.54 \\
\hline
\end{tabular}

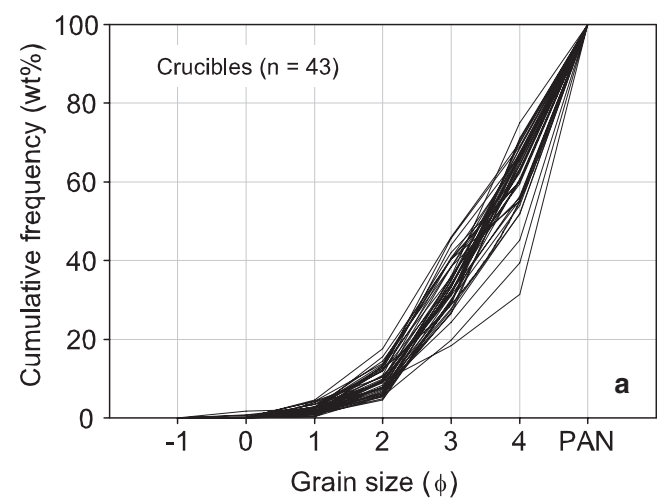

samples (Eramo 2005b), as reported by old glassmaking treatises, suggests that this practice was not economically and technologically relevant because of the abundance of suitable refractory earth deposits.

The differences between crucibles and refractory samples are minimal, indicating that the natural raw material was considered technologically valid for both. They are characterized by fine monocrystalline quartz sand, which minimized the thermal expansion problems and gave more stability to the artefacts (Hübner 1991). Normative calculation of the original mineralogical compositions for the crucible fragments indicates about $20 \mathrm{wt} \%$ of kaolinite (Eramo 2005b). This clay mineral supplied enough plasticity to the raw material to form the crucibles and bricks, and to be applied as a

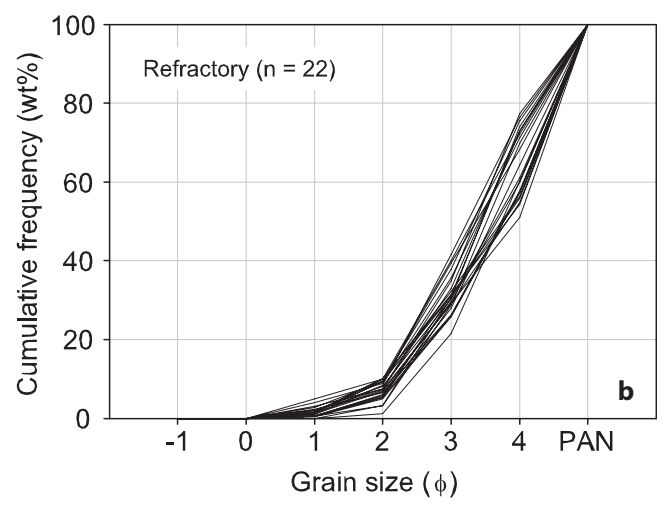

Table 5. PCA of the archaeological and natural samples: eigenvalues of the correlation matrix

\begin{tabular}{lcrr}
\hline Component & Eigenvalue & $\begin{array}{c}\% \text { of } \\
\text { variance }\end{array}$ & $\begin{array}{c}\text { Cumulative } \\
\%\end{array}$ \\
\hline 1 & 5.85 & 41.78 & 41.78 \\
2 & 2.00 & 14.31 & 56.09 \\
3 & 1.40 & 9.97 & 66.07 \\
4 & 1.33 & 9.53 & 75.59 \\
5 & 0.91 & 6.49 & 82.09 \\
6 & 0.68 & 4.84 & 86.92 \\
7 & 0.64 & 4.61 & 91.53 \\
8 & 0.36 & 2.56 & 94.09 \\
9 & 0.33 & 2.32 & 96.42 \\
10 & 0.25 & 1.77 & 98.18 \\
11 & 0.15 & 1.10 & 99.29 \\
12 & 0.07 & 0.51 & 99.79 \\
13 & 0.03 & 0.18 & 99.98 \\
14 & 0.00 & 0.02 & 100.00 \\
\hline
\end{tabular}

Fig. 4. Cumulative grain-size frequency curves of crucible (a) and refractory samples (b) obtained by thin-section analysis. 
Table 6. PCA of the archaeological and natural samples: loadings of the first three PC

\begin{tabular}{lrrr}
\hline & \multicolumn{1}{c}{ PC1 } & \multicolumn{1}{c}{ PC2 } & \multicolumn{1}{c}{ PC3 } \\
\hline $\mathrm{SiO}_{2}$ & -0.834 & 0.113 & 0.276 \\
$\mathrm{TiO}_{2}$ & 0.596 & 0.552 & 0.201 \\
$\mathrm{Al}_{2} \mathrm{O}_{3}$ & 0.759 & 0.245 & -0.384 \\
$\mathrm{Fe}_{2} \mathrm{O}_{3 \text { tot }}$ & 0.535 & -0.266 & 0.269 \\
$\mathrm{MgO}$ & 0.592 & -0.273 & 0.517 \\
$\mathrm{CaO}$ & 0.234 & -0.456 & -0.297 \\
$\mathrm{~K}_{2} \mathrm{O}$ & 0.785 & -0.188 & 0.147 \\
$\mathrm{Cr}$ & 0.788 & 0.421 & 0.005 \\
$\mathrm{Sr}$ & 0.545 & -0.361 & -0.368 \\
$\mathrm{Zr}$ & 0.448 & 0.409 & 0.608 \\
$2 \phi$ & -0.547 & -0.536 & 0.353 \\
$3 \phi$ & -0.790 & 0.066 & 0.057 \\
$4 \phi$ & -0.374 & 0.654 & -0.222 \\
pan & 0.856 & -0.206 & -0.017 \\
\hline
\end{tabular}

plaster in the melting chamber. Moreover, its low shrinkage reduced the formation of cracks in the artefact, increasing the mechanical resistance. Such a composition (i.e. Qtz $80 \mathrm{wt} \%+\mathrm{Kln}$ $20 \mathrm{wt} \%$ ) has a softening point of about $1600{ }^{\circ} \mathrm{C}$ (Aramaky \& Roy 1962) and hence guarantees good refractory behaviour in service conditions (up to $1500{ }^{\circ} \mathrm{C}$ ). A low $\mathrm{Fe}_{2} \mathrm{O}_{3 \text { tot }}$ content is very important for refractory materials used in glassmaking. Even a few percent of $\mathrm{Fe}_{2} \mathrm{O}_{3 \text { tot }}$ may compromise the colour of glass and, of course, lower the eutectic point of the refractory materials.

This paper is part of a $\mathrm{PhD}$ thesis in Archaeometry at the University of Fribourg (Switzerland). I am grateful to M. Maggetti and G. Thierrin-Michael for their continuous support and guidance. C. Gerber and N. Stork
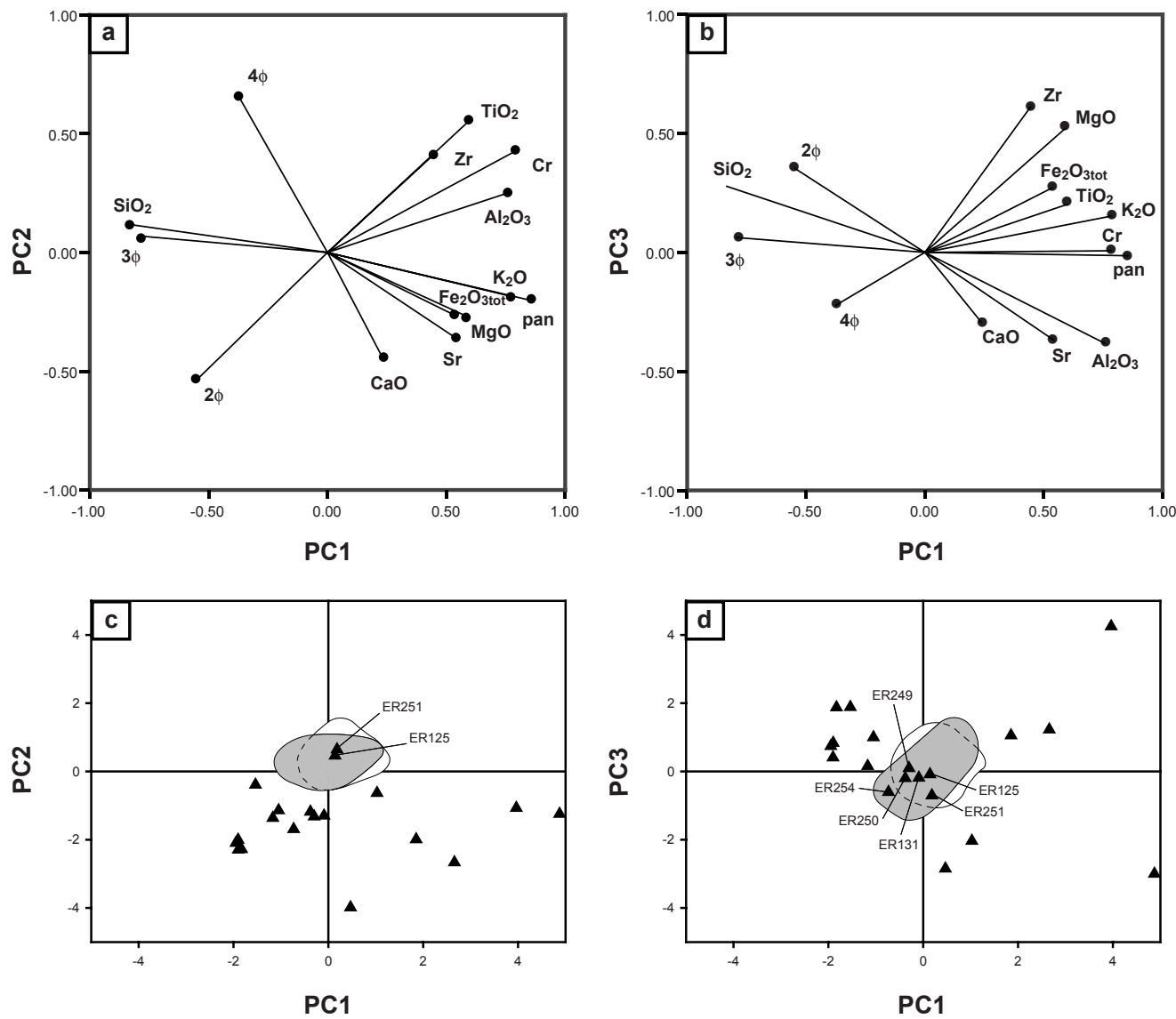

Fig. 5. The component plots of PC1 v. PC2 (a) and PC1 v. PC3 (b) showing the contributions to the PC variance and the correlations between variables (see text for details). Scatter plots of the PC scores using PC1 v. PC2 and PC1 v. PC3 are shown in (c) and (d), respectively. In (c) only two Hupper sand samples (ER125 and 251) fit the crucible and refractory samples, whereas in (d) four other samples (ER131, 249, 250 and 254) are compatible with the archaeological materials. White area, crucibles; grey area, refractory samples; $\boldsymbol{\Lambda}$, Hupper sand. 
are gratefully acknowledged for their help in surveying and sampling. I am indebted to V. Serneels (University of Fribourg) for XRF analyses.

\section{Appendix}

\section{Sample weight}

The Hupper sand samples were quartered until a $75 \mathrm{~g}$ portion was obtained. This portion was used for sieving $(50 \mathrm{~g})$, for thin-section preparation (c. $5 \mathrm{~g}$ ) and for XRD and XRF (c. $20 \mathrm{~g}$, powdered).

\section{Petrographic analysis}

Five samples of Hupper sand (ER125, 136, 248, 250 and 255) were impregnated with epoxy resin to obtain thin sections, which were analysed under a Carl Zeiss Standard polarizing microscope.

\section{$X$-ray diffraction $(X R D)$}

The mineral composition was resolved by XRD analyses carried out on a Philips PW1800 diffractometer with $\mathrm{Cu}-\mathrm{K}_{\alpha}$ radiation at $40 \mathrm{kV}$ and $40 \mathrm{~mA}$ (step angle of $0.02^{\circ}, 2 \theta$ from $2^{\circ}$ to $65^{\circ}$, measuring time $1 \mathrm{~s}$ per step).

\section{Loss on ignition (LOI)}

Dry powdered sample $(3 \mathrm{~g})$ was calcined at $1000{ }^{\circ} \mathrm{C}$ for $1 \mathrm{~h}$ and weighed to determine the LOI.

\section{$X$-ray fluorescence $(X R F)$}

Analyses were carried out on glassy tablets, prepared by melting $0.700 \mathrm{~g}$ of calcined samples, $0.350 \mathrm{~g}$ of Li fluoride and $6.650 \mathrm{~g}$ of Li tetraborate at $1150{ }^{\circ} \mathrm{C}$ in a Pt crucible. Bulk chemical analyses for major and trace elements were performed using a Philips PW 2400 XRF spectrometer equipped with a rhodium X-ray tube. As the standards used do not cover the very high percentages of $\mathrm{SiO}_{2}$ in the samples, deviations up to $4 \mathrm{wt} \%$ from $100 \mathrm{wt} \%$ occur (Table 2).

Table 7. Precision of the grain-size analyses by point counting $(p c)$ and sieving $(s)$

\begin{tabular}{|c|c|c|c|c|c|c|c|}
\hline $\begin{array}{l}\phi: \\
\mathrm{mm}:\end{array}$ & $\begin{array}{l}<-1 \\
>2\end{array}$ & $\begin{array}{c}-1-0 \\
1-2\end{array}$ & $\begin{array}{l}0-1 \\
0.5-1\end{array}$ & $\begin{array}{l}1-2 \\
0.25-0.5\end{array}$ & $\begin{array}{l}2-3 \\
0.125-0.25\end{array}$ & $\begin{array}{l}3-4 \\
0.063-0.125\end{array}$ & $\begin{array}{l}>4 \\
<0.063\end{array}$ \\
\hline $\begin{array}{l}E R 125 p c \\
\text { mean }\end{array}$ & 0.00 & 0.00 & 0.87 & 7.00 & 15.16 & 19.48 & 57.49 \\
\hline $\begin{array}{l}\sigma \\
E R 125 s\end{array}$ & 0.00 & 0.00 & 0.58 & 1.03 & 0.39 & 0.93 & 1.25 \\
\hline mean & 0.00 & 0.23 & 1.65 & 9.35 & 22.19 & 21.33 & 45.24 \\
\hline $\begin{array}{l}\sigma \\
E R 136 p c\end{array}$ & 0.00 & 0.15 & 0.52 & 0.35 & 2.67 & 1.43 & 3.02 \\
\hline mean & 0.00 & 0.00 & 0.06 & 2.98 & 16.59 & 10.98 & 69.39 \\
\hline $\begin{array}{l}\sigma \\
\text { ER136s }\end{array}$ & 0.00 & 0.00 & 0.10 & 0.57 & 0.23 & 0.21 & 0.81 \\
\hline mean & 0.78 & 0.02 & 0.23 & 8.07 & 14.72 & 9.01 & 67.18 \\
\hline $\begin{array}{l}\sigma \\
E R 248 p c\end{array}$ & 0.08 & 0.01 & 0.01 & 2.45 & 0.89 & 1.33 & 1.93 \\
\hline mean & 0.00 & 0.00 & 0.00 & 1.56 & 3.19 & 1.72 & 93.53 \\
\hline $\begin{array}{l}\sigma \\
E R 248 s\end{array}$ & 0.00 & 0.00 & 0.00 & 0.47 & 0.91 & 0.32 & 0.71 \\
\hline mean & 0.04 & 0.04 & 0.06 & 0.3 & 0.98 & 1.96 & 96.62 \\
\hline $\begin{array}{l}\sigma \\
E R 250 p c\end{array}$ & 0.01 & 0.02 & 0.01 & 0.65 & 0.80 & 0.97 & 1.23 \\
\hline mean & 0.00 & 0.00 & 3.78 & 12.91 & 30.11 & 19.15 & 34.05 \\
\hline $\begin{array}{l}\sigma \\
E R 250 s\end{array}$ & 0.00 & 0.00 & 0.71 & 2.01 & 1.55 & 2.55 & 2.93 \\
\hline mean & 0.27 & 0.85 & 4.00 & 16.44 & 27.58 & 12.99 & 37.88 \\
\hline $\begin{array}{l}\sigma \\
E R 255 p c\end{array}$ & 0.15 & 0.20 & 0.62 & 1.24 & 1.71 & 1.82 & 2.24 \\
\hline mean & 0.00 & 0.00 & 1.46 & 2.61 & 18.54 & 11.87 & 65.52 \\
\hline $\begin{array}{l}\sigma \\
E R 255 s\end{array}$ & 0.00 & 0.00 & 0.12 & 0.57 & 0.43 & 0.67 & 0.36 \\
\hline mean & 0.23 & 0.64 & 1.03 & 2.98 & 17.87 & 7.99 & 69.25 \\
\hline$\sigma$ & 0.08 & 0.28 & 0.18 & 0.37 & 2.79 & 0.46 & 2.44 \\
\hline
\end{tabular}

Means of the percentages of three-time repeated analyses and the standard deviations are shown. 


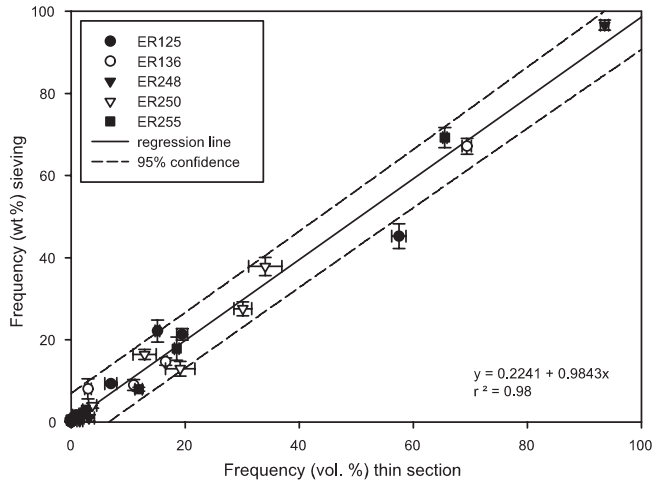

Fig. 6. Linear regression of the grain-size frequencies determined on the five test samples by point counting in thin sections and sieve analysis. The standard deviation bars based on the three repeat measurements are shown. Dotted lines represent the $95 \%$ confidence limits around the regression line.

\section{Grain-size analysis by sieving}

Grain-size distribution data were obtained by wet sieving. Fifty grams of each Hupper sand sample were analysed. The samples were dispersed in water and exposed to ultrasound waves to separate sand grains from clay. Six sieves with different aperture sizes $(63,125,250,500,1000$ and $2000 \mu \mathrm{m})$ and a terminal pan to retain the $<63 \mu \mathrm{m}$ fraction were used. The analyses were performed with the aid of a Fritsch shaker for 30 min per sample. The size fractions (pan content included) were dried and weighed, and their percentages were normalized to $100 \mathrm{wt} \%$. The precision of the sieving method was assessed by repeating three times the analysis on samples ER125, 136, 248, 250 and 255 (Table 7).

\section{Grain-size analysis in thin section}

Twenty-two thin sections of refractory materials (reported as unit $\zeta$ by Eramo 2005a) and 43 of the melting crucibles (Eramo 2005b) were analysed. Moreover, five thin sections of Hupper samples (ER125, 136, 248, 250 and 255), with different grain-size distribution, were analysed to estimate the precision of this method (Table 7). A Swift \& Sons point counter, mounted on the petrographic microscope, was used (with $1 / 3 \mathrm{~mm}$ as both line distance and lateral step). The maximum apparent diameter of grains was measured with the aid of a micrometer eyepiece at $10 \times$ magnification. The same size classes as in sieving were distinguished. Between 500 and 600 points per thin section were counted as the minimum number of counts necessary for routine analyses (Friedman 1958). Grain-size data were reported in $\phi$ values (Tables 3 and 4 ) and are represented by cumulative frequency curves (Figs 3 and 4).

\section{Precision of the grain-size analyses}

The two methods provide grain-size frequencies from weight percentages (sieving) and from number of counts (thin section). The grain-size frequencies obtained by the two methods on the five test samples are plotted against each other in Figure 6. The correlation coefficient $\left(r^{2}=0.98\right)$ is highly significant and only one out of 35 observations lies outside the $95 \%$ confidence limits. Such a result shows that the grain-size analysis data in thin section have a precision comparable at the $95 \%$ level of significance with that of sieving. Underestimation of the particle size in thin section as a result of a sectioning effect (Krumbein 1935) was not relevant in PCA because of standardization of variables.

\section{References}

Amweg, G. 1941. Verrerie. In: Les Arts dans le Jura bernois et à Bienne, Arts appliqués, Tome II. Porrentruy, 403-446.

ARAMAKY, S. \& RoY, R. 1962. Revised phase diagram for the system $\mathrm{Al}_{2} \mathrm{O}_{3}-\mathrm{SiO}_{2}$. Journal of the American Ceramic Society, 45, 229-242.

Aubert, D. 1975. L'évolution du relief jurassien. Eclogae Geologicae Helvetiae, 68(1), 1-64.

BRILL, R. H. 1999. Chemical Analysis Of Early Glasses. Vol. 2, Tables of Analyses. Corning Museum of Glass, New York.

CABLE, M. 1998. The operation of wood fired glass melting furnaces. In: MCCRAY, P. (ed.) \& Kingery, W. D. (series ed.) The Prehistory and History of Glassmaking Technology, Ceramics and Civilisation Series, Vol. 8. American Ceramic Society, Westerville, OH, 315-329.

Cable, M. \& Smedley, J. W. 1987. Liquidus temperatures and melting characteristics of some early container glasses. Glass Technology, 28, 94-98.

Charleston, R. J. 1978. Glass furnaces through the ages. Journal of Glass Studies, 20, 9-33.

De Quervain, F. 1969. Die nutzbaren Gesteine der Schweiz. Kümmerly and Frey, Bern, 248-250.

Eramo, G. (2005a). The melting furnace of the Derrière Sairoche glassworks (Court, Swiss Jura): heat-induced mineralogical transformations and their technological signification. Archaeometry, 47, 571-592.

Eramo, G. (2005b). The glass-melting crucibles of Derrière Sairoche (1699-1714 AD, Ct. Bern, Switzerland): a petrological approach. Journal of Archaeological Sciences, doi: 10.1016/j.jas. 2005.09.002.

FleUry, E. 1909. Le Sidérolithique suisse. Mémoires de la Société fribourgeoise de Sciences naturelles, 6, $1-260$. 
Friedman, G. M. 1958. Determination of sieve-size distribution from thin-section data for sedimentary petrological studies. Journal of Geology, 66, 394-416.

Gerber, C. 2003. Court-Chaluet bei Moutier (Berner Jura, Schweiz): eine Schwarzwälder Glashütte. In: Steppunn, P. (ed.) Glashütten im Gespräch. Berichte und Materialien vom 2 Internationalen Symposium zur archäologischen Erforschung mittelalterlicher und frühneuzeitlicher Glashütten Europas. Schmidt-Römhild, Lübeck, 64-69.

Gerber, C., Portmann, M. \& Künding, C. 2002. Fours à chaux, four à fer et charbonnières dans le Jura bernois. Direction de l'instruction publique du canton de Berne, Berne.

Henderson, J. 2000. The Science and Archaeology of Materials. An Investigation of Inorganic Materials. Routledge, London.

Hoffmann, F. \& Peters, T. 1969. Untersuchungen über die Verwendbarkeit schweizerischer Rohstoffe als Bindetone für Giessereiformsande. Beiträge zur Geologie der Schweiz, Geotechnische Serie, Lieferung, 47, 27.

HÜBNER, G. 1991. Natural and synthetic raw materials for technical ceramics. European Journal of Mineralogy, 3, 651-665.

KRETZ, R. 1983. Symbols for rock-forming minerals. American Mineralogist, 68, 277-279.

Krumbein, W. C. 1935. Thin-section mechanical analysis of indurated sediments. Journal of Geology, 43, $482-496$

Kündig, R., Mumenthaler, T., Eckardt, P., et al. 1997. Die Mineralischen Rohstoffe der Schweiz. Schweizerische Geotechnische Kommission, Bern.
MicheL, G. J. 1989. Verriers et verreries en FrancheComté au XVIII ème siècle (2 volumes). Collection Recherches, ERTI, Paris.

PfirTer, U. 1997. Feuille 1106, Moutier. Atlas géologique Suisse, 1:25 000. Notice explicatives, 96.

SCHLAICH, E. 1934. Geologische Beschreibung der Gegend von Court im Berner Jura: mit Berücksichtigung der Molassebildungen. Beiträge zur geologischen Karte der Schweiz, 26, 1-41.

STERN, W. B. 1991. Zur chemischen Analyse der Bieler Gläser. In: GLATZ, R. (ed.) Hohlglasfunde der Region Biel, Zur Glasproduktion im Jura. Paul Haupt, Bern, 83-86.

Stern, W. B. \& Gerber, Y. 2004. Potassiumcalcium glass: new data and experiments. Archaeometry, 30(1), 137-156.

Sternini, M. 1995. La fenice di sabbia. Storia e tecnologia del vetro antico. Edipuglia, Bari.

Sveva GaI, A. 1991. La produzione del vetro preindustriale in Germania sudoccidentale. Stato delle ricerche e prospettive. In: MenderA, M. (ed.) Archeologia e storia della produzione del vetro preindustriale. All'insegna del giglio, Firenze, $375-410$.

Thurmann, J. 1836. Essai sur les soulèvements jurassiques. $2^{\text {eme }}$ cahier, avec la carte du Jura bernoise.

TURNer, W. E. S. 1956. Studies in ancient glasses and glassmaking processes. Part V. Raw materials and melting processes. Journal of the Society of Glass Technology, 40, 277-300.

Von Moos, A. 1941. Über Vorkommen und Abbau von Giessereiformstoffen in der Schweiz. Eclogae Geologicae Helvetiae, 34(2), 229-240. 
